\title{
Synthesis and Ring Transformation of Oxygen and Nitrogen Spiro Bisheterocycles
}

\author{
Oualid Talhi*a,b \\ Diana C. G. A. Pinto ${ }^{a}$ \\ Filipe A. Almeida Paz \\ Maamar Hamdid \\ Artur M. S. Silva*a \\ a QOPNA, Department of Chemistry, University of Aveiro, \\ 3810-193 Aveiro, Portugal \\ artur.silva@ua.pt \\ oualid.talhi@ua.pt \\ ${ }^{b}$ Centre de Recherche Scientifique et Technique en Analyses \\ Physico-Chimiques CRAPC, BP384, Bou-Ismail, 42004, Tipaza, \\ Algeria \\ ' CICECO Department of Chemistry, University of Aveiro, \\ 3810-193 Aveiro, Portugal \\ d Département de Chimie, USTHB, BP32 El Alia, Bab Ezzouar, \\ 16111 Alger, Algeria \\ Received: 28.09.2014 \\ Accepted: 02.11.2014 \\ Published online: 09.12 .2014 \\ DOI: 10.1055/s-0034-1379613; Art ID: st-2014-d0816-I \\ Abstract A facile and rapid access to bridgehead oxygen- and nitro- \\ gen-containing spiro bisheterocycles is reported. It involves a one-pot \\ spiro-to-spiro ring transformation of the key spiro[chromanone-hydan- \\ toin] compounds into new substituted spiro [hydantoin-diazole], spiro \\ [hydantoin-isoxazole], spiro [hydantoin-diazepine], spiro [hydantoin- \\ oxazepine], and spiro [hydantoin-benzodiazepine] upon reaction with \\ appropriate bisnucleophilic agents. The hydantoin cycle is preserved \\ during these chemical reactions affording the spiro bisheterocycles in \\ optimal yields (42-71\%). This relevant spiro-to-spiro ring transforma- \\ tion was confirmed by NMR and single-crystal X-ray diffraction studies.
}

Key words spiro bisheterocycles, oxygen and nitrogen heterocycles, bisnucleophiles, NMR, X-ray diffraction

Spiro compounds featuring bridgehead bisheterocycles are 'privileged structures' because they contain a spiro linkage and oxygen- and nitrogen-containing heterocycles that are currently important pharmacophores developed in the modern drug discovery. ${ }^{1-8}$ Spiro compounds belong to an outstanding class of natural and synthetic products which are simply defined as two-ring systems orthogonally positioned and connected by one common carbon atom adopting the $\mathrm{sp}^{3}$ tetrahedral hybridization. Looking to such a structural feature, various chemotypes of combined spiro bisheterocycles with significance in medicinal chemistry are reported. For example, spiro-oxindole compounds have gained interest, being successfully used as models for protein-protein interactions in the context of enhanced cancer therapy. ${ }^{1}$ Spiro scaffolds are frequently found in many interesting compounds exhibiting relevant biological activities and medicinal responses, such as antibiotic, ${ }^{3}$ antimalarial, and cytotoxicity against cancer cell lines (KB, BC, and $\mathrm{NCI}-\mathrm{H} 187) .{ }^{4}$ Spiro bisheterocycles are also used in pharmaceutical compositions for the treatment of Alzheimer's disease, insulin resistance syndrome, and type 2 diabetes. $^{5}$
Aryl-fused spiro cyclic compounds are also suitable to inhibit histone deacetylase, selective inducing terminal differentiation, arresting cell growth, apoptosis of neoplastic cells, and inhibiting cancer cell proliferation. ${ }^{7}$ Spiro pyrans and spiro oxazines have found important technological applications being used as storage materials for memories and switches due to their photochromic properties. ${ }^{8}$

Although the referred important applications of spiro compounds, only a countable number of reports have efficiently reported the design and development of synthetic strategies of spiro bisheterocyclic scaffolds, involving multicomponent ${ }^{9-13}$ and multistep reactions. ${ }^{14-16}$ For example, we can highlight a three-component Biginelli-like condensation, ${ }^{9}$ an iodine-catalyzed four-component reaction of an aldehyde, urea or thiourea, and cyclic 1,3-dicarbonyl compounds, ${ }^{10}$ a multicomponent copper-mediated 1,3-dipolar cycloaddition of azomethine ylides with several dipolarophiles, ${ }^{11}$ and of the Huisgen zwitterion with benzofuran2,3-diones. ${ }^{13}$

Despite of these promising results, tracking efficient and updated methods for the construction of spiro compounds remains an attractive goal, especially due to their structural and biorelevant properties. The importance of such compounds can be envisaged in a possible mimicking of structural motifs found in proteins, thereby, increasing the probability of interactions with biological systems.

In this manuscript we discuss the development of economic synthetic routes towards a new generation of spiro bisheterocycles. Our work started by the preparation of the reported spiro[chromanone-hydantoin] compounds 1a,b from chromone-2-carboxylic acid and carbodiimides using an organocatalytic procedure. ${ }^{17}$ These key starting materials were then treated with bisnucleophiles, such as methylhydrazine, hydroxylamine, ethylenediamine, hydroxyethyleneamine, and ortho-phenylenediamine. This synthetic route allowed an interesting one-pot spiro-to-spiro ring transformation of the chromanone residue of $\mathbf{1 a}, \mathbf{b}$ to di- 
azole $\mathbf{2 a},{ }^{18}$ isoxazole $\mathbf{3 a},{ }^{19}$ diazepine $\mathbf{4 a}, \mathbf{b},{ }^{20}$ oxazepine $\mathbf{5 a},{ }^{21}$ and benzodiazepine $\mathbf{6} \mathbf{a}, \mathbf{b}^{22}$ maintaining the hydantoin heterocycle unchanged during the course of the reaction. All these transformations are carried out under soft operating conditions affording optimal yields (42-71\% after chromatographic purification and recrystallization, Scheme 1). ${ }^{18-22}$ The action of bisnucleophiles, such as diamines, on compounds 1a,b was mechanistically expected to result in a one-step spiro-to-spiro ring transformation of the chromanone heterocycle through consecutive nucleophilic attacks including the amine condensation with the carbonyl C-4 (imine formation) and chromanone ring opening over the spiro tetrahedral carbon $\mathrm{C}-2$ to give rise the new heterocyclic closure. Compounds $\mathbf{1 a} \mathbf{a}, \mathbf{b}$ are indeed very reactive in front of tethered nucleophiles (e.g., nitrogen and oxygen), which may favor rearrangements or ring opening especially via heterolytic cleavage over the highly polarized $\mathrm{O}-\mathrm{C} \sigma$ bond of the chromanone, rather than the N-C one of the hydantoin nucleus which is found more chemically robust. ${ }^{17}$ Evidence for the mechanistic sequence was, however, found by the isolation of the side product $\mathbf{7 b}$ (yield $8 \%$ ) formed in organobase media of ethylenediamine when this latter is brought to react with $\mathbf{1 b}$ in order to yield the spiro product 4b $(67 \%$, Scheme 1$)$. The reaction is probably initiated by a deprotonation at the active methylene $\mathrm{C}-3$ of $\mathbf{1} \mathbf{a}, \mathbf{b}$ causing a chromanone ring opening to yield the possibly isolated intermediate $\mathbf{7 b}$ (isolated only in case of the reaction between 1b and ethylenediamine). ${ }^{20}$ Such an intermediary $\alpha, \beta$-unsaturated ketone system $\mathbf{7 b}$ is found ready to undergo the classical condensation with bisnucleophilic agents (such as the systems of $\mathrm{NH}_{2}-\cdot-\mathrm{NH}_{2}$ or $\mathrm{NH}_{2}-\cdot-\mathrm{OH}$ ) via imine formation followed by an aza- (or oxa-) Michael addition. Therefore, the new heterocycle closure takes place giving rise to various spiro bridgehead ring systems depending on the spacer used in the bisnucleophilic agent (Scheme 2). Similar reaction mechanism has been proposed in our previous work, ${ }^{17}$ since the intermediary $\alpha, \beta$-unsaturated ketone structure 7 could also be isolated in low quantities under inorganic base treatment of $\mathbf{1 a}, \mathbf{b}$ using sodium ethoxide (EtONa).

The novel synthetic procedure herein reported has several advantages including mild synthetic conditions (with or without catalyst) and allowed the synthesis of a wide range of spiro asymmetric bisheterocyclic compounds. The structural features of these spiro bisheterocycles 2-6 were finely established based on 1D and 2D NMR studies. The<smiles>[R]N1C(=O)N([R])[C@@]2(CC(c3ccccc3O)=NCCO2)C1=O</smiles><smiles>[R]N1C(=O)N([R])C2(CC(c3ccccc3O)=Nc3ccccc3N2)C1=O</smiles>

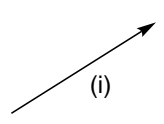

(iv)<smiles>[R]N1C(=O)N([R])C2(CC(=O)c3ccccc3O2)C1=O</smiles>

$1 \mathrm{a}, \mathrm{b}$<smiles>[R]N1C(=O)N([2H])C(=O)[C@]12CC(c1ccccc1O)=NN2C</smiles>

(ii)<smiles>[R]N1C(=O)N([2H])C2(CC(c3ccccc3O)=NCCN2)C1=O</smiles><smiles>[R]N1C(=O)N([R])[C@@]2(CC(c3ccccc3O)=NO2)C1=O</smiles>

3a $(42 \%)$

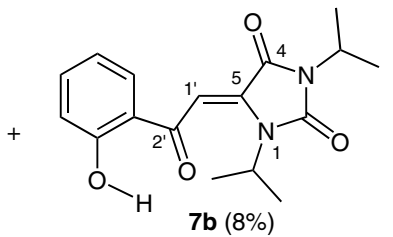

a $\mathrm{R}=c-\mathrm{Hex}$

b $\mathrm{R}=i-\mathrm{Pr}$

Scheme 1 Synthesis of spiro bisheterocycles 2-6. Reagents and conditions: (i) methylhydrazine, $\mathrm{CH}_{2} \mathrm{Cl}_{2}$, r.t.; (ii) hydroxylammonium chloride, $\mathrm{K}_{2} \mathrm{CO}_{3}$ (3 equiv), THF, reflux; (iii) ethylenediamine, $\mathrm{CH}_{2} \mathrm{Cl}_{2}$, r.t.; (iv) hydroxyethyleneamine, $\mathrm{CH}_{2} \mathrm{Cl}_{2}$, r.t.; (v) o-phenylenediamine, cat. DBU, THF, reflux.

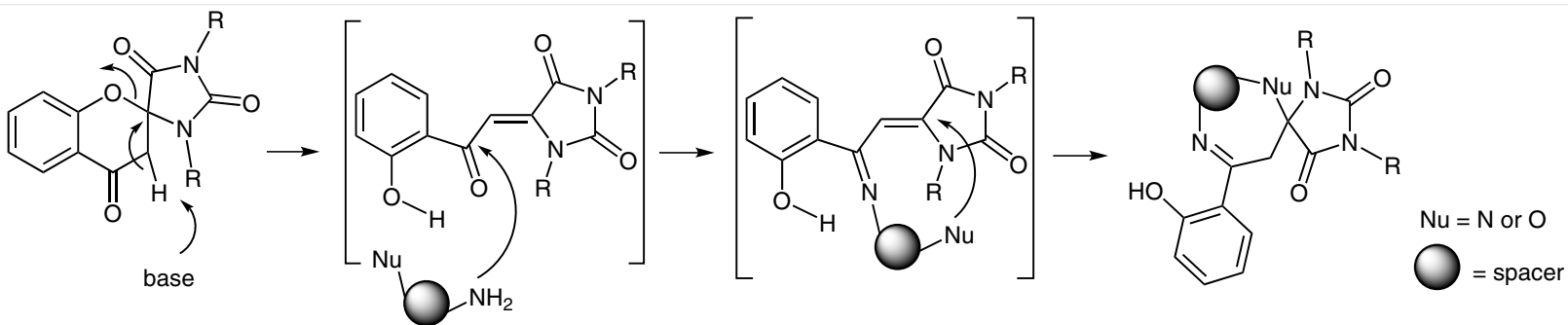

Scheme 2 Proposed mechanism for the formation of spiro bisheterocycles 2-6 
main feature revealed in the ${ }^{1} \mathrm{H}$ NMR spectra is the occurrence of geminal diastereotopic protons displaying a clear AB spin system $\left({ }^{2} J=14.0-17.8 \mathrm{~Hz}\right)$ with different chemicalshift values affected by the heteroatom neighbors. In most cases, the existence of an intramolecular hydrogen bond between the 2 "- $\mathrm{OH}$ of the phenyl group and the imine nitrogen function is markedly visible by the appearance of a singlet at higher frequency values ca. $\delta=11 \mathrm{ppm}$. The imine carbon is located in the ${ }^{13} \mathrm{C}$ NMR spectra at $\delta=149.5$ (diazole, 2a), 153.8 (isoxazole, 3a), 166.7-167.0 (benzodiazepine, 6a,b), 171.5 (diazepine, 4a,b), and 200.5 (oxazepine, 5a) ppm, which could be confirmed through HMBC correlations entertained with the geminal diastereotopic protons of the adjacent carbon. These protons further show important HMBC connectivities allowing the unequivocal assignment of the spiro carbon $(\delta=72.1-87.1 \mathrm{ppm})$, the carbonyl C -5 ' of the hydantoin cycle and the $\mathrm{C}-1$ " of the connected phenyl group (Figure 1).

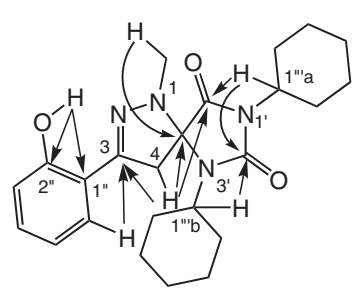

$2 a$

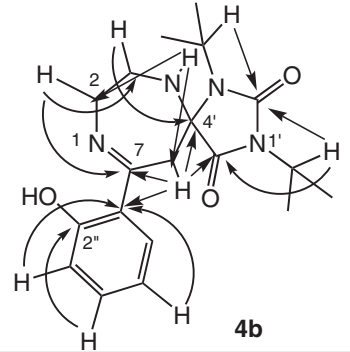

$4 b$
Figure 1 Main HMBC correlations of spiro bisheterocycles $\mathbf{2 a}$ and $\mathbf{4 b}$

We note, however, that our synthetic approach toward spiro bisheterocycles does not permit an enantioselective isolation of enantiomerically pure compounds, as observed from the X-ray diffraction studies performed on compounds $\mathbf{2 a}, \mathbf{4 b}$, and $\mathbf{6 b}$. $^{23-25}$ Good-quality crystals of these compounds were isolated from either a hexane-acetone (5:1) or a hexane-dichloromethane (5:1) mixture by a slow evaporation of the solvent (at $6{ }^{\circ} \mathrm{C}$ ). X-ray diffraction studies confirmed the structural features unveiled from the NMR investigations, showing the presence of three chiral spiro asymmetric bisheterocyclic compounds (the carbon stereocenters are depicted in Figure 2 by an asterisk). Nevertheless, because of compounds crystallize in centrosymmetric space groups (i.e., $C 2 / c$ for $\mathbf{2 a}$ and $P 2_{1} / \mathbf{n}$ for $\mathbf{4 b}$ and 6b), the unit cell contains as well the mirror image of each molecule leading to solid-state racemic mixtures of the two possible enantiomers for each compound. In addition, the crystallization of the molecular units in compounds $\mathbf{2 a}$ and $\mathbf{6 b}$ is further accompanied by the inclusion of solvent molecules in the interstices of the crystal structure, namely acetone and dichloromethane, respectively. A common structural feature among all compounds concerns the presence of intramolecular hydrogen bonds interconnecting the 2"$\mathrm{OH}$ groups of the phenyl groups to the neighboring nitrogen of the imine $\mathrm{C}=\mathrm{N}$ functional group (dashed green lines in Figure 2).
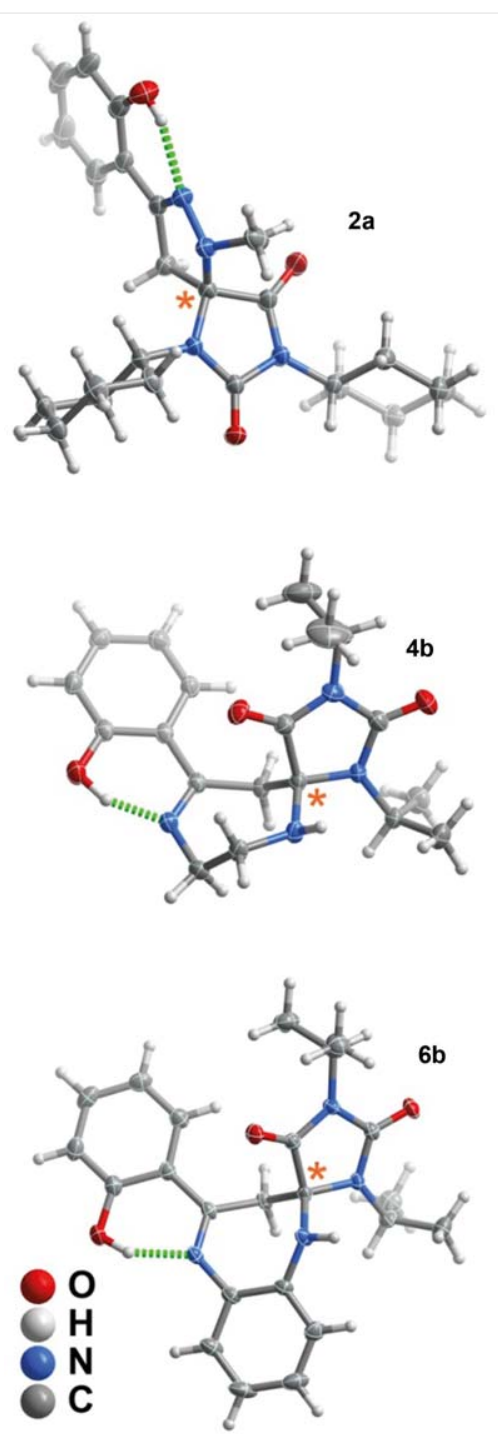

Figure 2 Schematic representations of the spiro asymmetric bisheterocyclic moieties composing the asymmetric units of the crystal structures of compounds $\mathbf{2 a}, \mathbf{4} \mathbf{b}$, and $\mathbf{6} \mathbf{b}$. Nonhydrogen atoms are represented as thermal ellipsoids drawn at the $50 \%$ probability level and hydrogen atoms as small spheres with arbitrary radii. Carbon stereocenters are depicted by an asterisk. The solvent molecules present in the asymmetric units of compounds $\mathbf{2} \mathbf{a}$ and $\mathbf{6} \mathbf{b}$ (acetone and dichloromethane, respectively), have been omitted for clarity.

In summary, we described the creation of a novel library of spiro bisheterocycles via simple synthetic routes based on the spiro-to-spiro ring transformation of the easily accessible spiro[chromanone-hydantoin] compounds into a large diversity of nitrogen- and oxygen-containing heterocycles linked to the hydantoin ring. The newly established library of compounds would receive a great interest for future biological screening especially in neuropathological models due to the longstanding use of hydantoin and diazepine structures in this medicinal domain. 


\section{Acknowledgment}

Thanks are due to the University of Aveiro, Fundação para a Ciência e a Tecnologia (Portugal), EU, QREN, FEDER, COMPETE, for funding the Organic Chemistry Research Unit (project PEst-C/QUI/UI0062/2013) and the Portuguese National NMR Network (RNRMN). We would like to thank the General Directorate for Scientific Research and Technological Development-DGRSDT of Algeria for the financial support. O. Talhi also thanks the project New Strategies Applied to Neuropathological Disorders (CENTRO-07-ST24-FEDER-002034), co-funded by QREN, "Mais Centro-Programa Operacional Regional do Centro" and EU, FEDER for his post-doctoral position. We further wish to thank the Associated Laboratory CICECO (FCT grant PEstC/CTM/LA0011/2013; FCOMP-01-0124-FEDER-037271) for funding the purchase of the single-crystal X-ray diffractometer.

\section{Supporting Information}

Supporting information for this article is available online at http://dx.doi.org/10.1055/s-0034-1379613.

\section{References and Notes}

(1) (a) Rompaey, K. V.; Ballet, S.; Tömböly, C.; De Wachter, R.; Vanommeslaeghe, K.; Biesemans, M.; Willem, R.; Tourwé, D. Eur. J. Org. Chem. 2006, 13, 2899. (b) Somu, R. V.; Johnson, R. L. J. Org. Chem. 2005, 70, 5954. (c) Genin, M. J.; Mishra, R. K.; Johnson, R. L. J. Med. Chem. 1993, 36, 3481.

(2) Zhao, Y.; Bernard, D.; Wang, S. BioDiscovery 2013, 8, 1.

(3) Cottin, T.; Pyrkotis, C.; Stathakis, C. I.; Mavridis, I.; Katsoulis, I. A.; Anastasopoulou, P.; Kythreoti, G.; Zografos, A. L.; Nahmias, V. R.; Papakyriakou, A.; Vourloumis, D. ChemBioChem 2011, 12, 71.

(4) Bunyapaiboonsri, T.; Yoiprommarat, S.; Intereya, K.; Rachtawee, P.; Hywel-Jones, N. L.; Isaka, M. J. Nat. Prod. 2009, 72, 756.

(5) Fisher, A.; Bar-Ner, N.; Nachum, V. US 20110281903, 2011.

(6) Fourtillan, J.-B. PCT/FR 1995000443, 1995.

(7) Hamblett, C. US 12227417, 2012.

(8) Berkovic, G.; Krongauz, V.; Weiss, V. Chem. Rev. 2000, 100, 1741.

(9) Svêtlík, J.; Kettmann, V. Tetrahedron Lett. 2011, 52, 1062.

(10) Prajapati, D.; Bhuyan, D.; Gohain, M.; Hu, W. Mol. Diversity 2011, 15, 257.

(11) Singh, S. N.; Regati, S.; Paul, A. K.; Layek, M.; Jayaprakash, S.; Reddy, K. V.; Deora, G. S.; Mukherjee, S.; Pal, M. Tetrahedron Lett. 2013, 54, 5448.

(12) Pal, S.; Khan, Md. N.; Karamthulla, S.; Abbas, Sk. J.; Choudhury, L. H. Tetrahedron Lett. 2013, 54, 5434.

(13) Wang, Z.-D.; Dong, N.; Wang, F.; Li, X.; Cheng, J.-P. Tetrahedron Lett. 2013, 54, 5473.

(14) Pesquet, A.; Othman, M. Tetrahedron Lett. 2013, 54, 5227.

(15) Azizian, J.; Shaabanzadeh, M.; Hatamjafari, F.; Mohammadizadeh, M. R. ARKIVOC 2006, (xi), 47.

(16) Kusanur, R. A.; Ghate, M.; Kulkarni, M. V.J. Chem. Sci. 2004, 116, 265.

(17) Talhi, O.; Fernandes, J. A.; Pinto, D. C. G. A.; Paz, F. A. A.; Silva, A. M. S. Tetrahedron 2013, 69, 5413.

(18) Synthesis of $(R, S)-1$ ',3'-Dicyclohexyl-3-(2"-hydroxyphenyl)spiro[1-methyl-4,5-dihydro-1H-pyrazole-5,4'-imidazolidine]-2',5'-dione (2a)

$\mathrm{C}_{24} \mathrm{H}_{32} \mathrm{~N}_{4} \mathrm{O}_{3}$ (white crystal, molecular weight $424.53 \mathrm{~g} / \mathrm{mol}, 0.65$ g, yield $61 \%$, mp $\left.118-120^{\circ} \mathrm{C}\right)$. Compound $\mathbf{1 a}(1 \mathrm{~g}, 2.5 \mathrm{mmol})$ was added to of methylhydrazine ( $1 \mathrm{~mL}, 18.8 \mathrm{mmol})$ in $\mathrm{CH}_{2} \mathrm{Cl}_{2}(20$ $\mathrm{mL}$ ). The reaction mixture was stirred at r.t. for $1 \mathrm{~h}$. After that, the volume of $\mathrm{CH}_{2} \mathrm{Cl}_{2}$ was reduced to ca. $5 \mathrm{~mL}$ to be purified in short plug column chromatography using $\mathrm{CH}_{2} \mathrm{Cl}_{2}$ as eluent. The purified product $\mathbf{2 a}$ was recrystallized from hexane-acetone (5:1) solution by slow evaporation at $6{ }^{\circ} \mathrm{C} .{ }^{1} \mathrm{H}$ NMR $(300.13$ $\mathrm{MHz}, \mathrm{CDCl}_{3}$ ): $\delta=1.09-2.25$ ( $\mathrm{m}, 20 \mathrm{H}, \mathrm{CH}_{2}$, cyclohexyl), 2.88 (s, 3 $\left.\mathrm{H}, \mathrm{NCH}_{3}\right), 3.13$ (tt, $\left.J=12.0,3.7 \mathrm{~Hz}, 1 \mathrm{H}, \mathrm{H}-1{ }^{\prime \prime \prime} \mathrm{b}\right), 3.35$ and 3.63 (AB, $J=17.7 \mathrm{~Hz}, 2 \mathrm{H}, \mathrm{H}-4), 3.91$ (tt, $J=12.4,3.9 \mathrm{~Hz}, 1 \mathrm{H}, \mathrm{H}-1$ '"a), 6.89 (ddd, $J=7.4,5.4,1.2 \mathrm{~Hz}, 1 \mathrm{H}, \mathrm{H}-5 "), 6.98-7.02$ (m, $2 \mathrm{H}, \mathrm{H}-$ $\left.3^{\prime \prime}\right), 7.08$ (dd, $\left.J=7.4,1.7 \mathrm{~Hz}, 1 \mathrm{H}, \mathrm{H}-6^{\prime \prime}\right), 7.23-7.29$ (m, $\left.1 \mathrm{H}, \mathrm{H}-4^{\prime \prime}\right)$, $10.39\left(\mathrm{~s}, 1 \mathrm{H}, 2\right.$ "-OH) ppm. ${ }^{13} \mathrm{C}$ NMR $\left(75.47 \mathrm{MHz}, \mathrm{CDCl}_{3}\right): \delta=$ 24.9, 25.0, 25.71, 25.71, 26.02, 26.03, 29.3, 29.5,30.2 and 30.9 $\left(\mathrm{CH}_{2}\right.$, cyclohexyl), $34.9\left(\mathrm{NCH}_{3}\right), 40.5$ (C-4), $51.4\left(\mathrm{C}-1^{\prime \prime \prime} \mathrm{a}\right), 53.5$ (C$\left.1^{\prime \prime \prime} b\right), 83.7$ (C-5/4'), 115.7 (C-1"), 116.7 (C-3"), 119.2 (C-5"), 126.8 (C-6"), 130.5 (C-4"), 149.5 (C-3), 153.9 (C-2'), 157.2 (C$\left.2^{\prime \prime}\right), 170.2\left(\mathrm{C}-5^{\prime}\right)$ ppm. HRMS (ESI $\left.{ }^{+}\right): \mathrm{m} / z$ calcd for $\left[\mathrm{C}_{24} \mathrm{H}_{32} \mathrm{~N}_{4} \mathrm{O}_{3}+\right.$ $\mathrm{Na}]^{+}:$447.2372; found: 447.2385.

(19) Synthesis of $(R, S)-1$ ',3'-Dicyclohexyl-3-(2"-hydroxyphenyl)spiro[4,5-dihydroisoxazole-5,4'-imidazolidine]-2',5'-dione (3a)

$\mathrm{C}_{23} \mathrm{H}_{29} \mathrm{~N}_{3} \mathrm{O}_{4}$ (yellowish white solid, molecular weight 411.49 $\mathrm{g} / \mathrm{mol}, 0.43 \mathrm{~g}$, yield $42 \%$, mp $\left.91-92{ }^{\circ} \mathrm{C}\right)$. Compound $1 \mathrm{a}(1 \mathrm{~g}, 2.5$ $\mathrm{mmol})$ was added to $\mathrm{K}_{2} \mathrm{CO}_{3}(1 \mathrm{~g}, 7.5 \mathrm{mmol})$ in acetone $(40 \mathrm{~mL})$. The reaction mixture was stirred at reflux to which hydroxylammonium chloride ( $1 \mathrm{~g}, 14.4 \mathrm{mmol}$ ) was gradually added over a period of $10 \mathrm{~min}$. After $15 \mathrm{~h}, \mathrm{~K}_{2} \mathrm{CO}_{3}$ was filtered off, and the solution was reduced to ca. $5 \mathrm{~mL}$ to which hexane $(25 \mathrm{~mL})$ was added. The purified product 3a was directly recrystallized from this hexane-acetone (5:1) solution by slow evaporation at $6{ }^{\circ} \mathrm{C}$ without any further purification steps. ${ }^{1} \mathrm{H}$ NMR $(300.13$ MHz, DMSO- $\left.d_{6}\right): \delta=1.00-1.99\left(\mathrm{~m}, 20 \mathrm{H}, \mathrm{CH}_{2}\right.$, cyclohexyl), 3.37 (tt, $\left.J=12.1,3.6 \mathrm{~Hz}, 1 \mathrm{H}, \mathrm{H}-1^{\prime \prime \prime} \mathrm{b}\right), 3.67$ (tt, $J=12.1,3.6 \mathrm{~Hz}, 1 \mathrm{H}, \mathrm{H}-$ $1^{\prime \prime \prime a), ~} 3.68$ and 3.71 (AB, $\left.J=15.4 \mathrm{~Hz}, 2 \mathrm{H}, \mathrm{H}-4\right), 7.40$ (ddd, $J=7.9$, 5.8, 2.1 Hz, $\left.1 \mathrm{H}, \mathrm{H}-5^{\prime \prime}\right), 7.62-7.66$ (m, $\left.2 \mathrm{H}, \mathrm{H}-3^{\prime \prime}, \mathrm{H}-4^{\prime \prime}\right), 7.87-7.91$ $\left(\mathrm{m}, 1 \mathrm{H}, \mathrm{H}-6^{\prime \prime}\right)$ ppm. ${ }^{13} \mathrm{C}$ NMR $\left(75.47 \mathrm{MHz}\right.$, DMSO- $\left.d_{6}\right): \delta=25.8$, 26.1, 26.3, 26.4, 26.80, 26.84, 29.3, 30.2, 31.4 and $31.8\left(\mathrm{CH}_{2}\right.$, cyclohexyl), 31.0 (C-4), 51.3 (C-1'"a), 53.0 (C-1"'b), 86.1 (C-5/4'), 110.2 (C-3"), 122.5 (C-1"), $123.1\left(\mathrm{C}-6^{\prime \prime}\right), 124.2\left(\mathrm{C}-5^{\prime \prime}\right), 131.0$ (C4"), 153.8 (C-3), 154.5 (C-2'), 163.5 (C-2"), 172.4 (C-5') ppm. HRMS (ESI $\left.{ }^{+}\right): \mathrm{m} / z$ calcd for $\left[\mathrm{C}_{23} \mathrm{H}_{29} \mathrm{~N}_{3} \mathrm{O}_{4}+\mathrm{Na}\right]^{+}:$: 434.2056; found: 434.2075.

(20) Synthesis of $(\boldsymbol{R}, S)-1$ ',3'-Dicyclohexyl-7-(2"-hydroxyphenyl)spiro $[(E)-3,4,5,6$-tetrahydro-2H-1,4-diazepine-5,4'-imidazolidine]-2',5'-dione (4a) and $(R, S)-1^{\prime}, 3^{\prime}$-Diisopropyl-7-(2"hydroxyphenyl)-spiro[(E)-3,4,5,6-tetrahydro-2H-1,4-diazepine-5,4'-imidazolidine]-2',5'-dione (4b)

Compound $\mathbf{1 a}(1 \mathrm{~g}, 2.5 \mathrm{mmol})$ or $\mathbf{1 b},(0.8 \mathrm{~g}, 2.5 \mathrm{mmol})$ was added to ethylenediamine ( $1 \mathrm{~mL}, 15 \mathrm{mmol})$ in $\mathrm{CH}_{2} \mathrm{Cl}_{2}(20 \mathrm{~mL})$. The reaction mixture was stirred at r.t. for $4 \mathrm{~h}$. After that, the volume of $\mathrm{CH}_{2} \mathrm{Cl}_{2}$ was reduced to ca. $5 \mathrm{~mL}$ to be purified in short plug column chromatography using $\mathrm{CH}_{2} \mathrm{Cl}_{2}$ as eluent. The purified products $\mathbf{4 a}$ or $\mathbf{4 b}$ were recrystallized from hexane- $\mathrm{CH}_{2} \mathrm{Cl}_{2}$ (5:1) solution by slow evaporation at $6{ }^{\circ} \mathrm{C}$. In the case of compound $\mathbf{4 b}$ synthesis, the byproduct $\mathbf{7 b}$ was isolated by column chromatography and precipitated in hexane.

Compound 4a: $\mathrm{C}_{25} \mathrm{H}_{34} \mathrm{~N}_{4} \mathrm{O}_{3}$ (pale yellow solid, molecular weight $438.56 \mathrm{~g} / \mathrm{mol}, 0.49 \mathrm{~g}$, yield $\left.45 \%, \mathrm{mp} 178-179{ }^{\circ} \mathrm{C}\right) .{ }^{1} \mathrm{H}$ NMR (300.13 MHz, $\left.\mathrm{CDCl}_{3}\right): \delta=1.06-2.34\left(\mathrm{~m}, 20 \mathrm{H}, \mathrm{CH}_{2}\right.$, cyclohexyl), 3.00-3.07 and 3.61-3.69 (2 m, $\left.2 \mathrm{H}, \mathrm{CH}_{2}, \mathrm{H}-3\right), 3.25$ and 3.34 (AB, $J=14.6,2 \mathrm{H}, \mathrm{H}-6), 3.24$ and $3.80(2 \mathrm{tt}, J=12.3,3.8 \mathrm{~Hz}, 2 \mathrm{H}, \mathrm{H}-$ 1 '"a, H-1"'b), 3.88 (ddd, $J=14.1,9.1,2.3 \mathrm{~Hz}, 1 \mathrm{H}, \mathrm{H}-2$ ), 4.17 (ddd, $J=14.1,6.6,1.8 \mathrm{~Hz}, 1 \mathrm{H}, \mathrm{H}-2$ ), 6.73 (ddd, $J=8.2,7.2,1.2 \mathrm{~Hz}, 1 \mathrm{H}$, 
H-5"), 6.93-6.98 (m, $\left.1 \mathrm{H}, \mathrm{H}-3^{\prime \prime}\right), 7.22$ (dd, $J=8.1,1.5 \mathrm{~Hz}, 1 \mathrm{H}, \mathrm{H}-$ 6"), 7.27-7.31 (m, $1 \mathrm{H}, \mathrm{H}-4$ "), 15.79 (s, $1 \mathrm{H}, 2$ "'-OH) ppm. ${ }^{13} \mathrm{C}$ $\operatorname{NMR}\left(75.47 \mathrm{MHz}, \mathrm{CDCl}_{3}\right): \delta=24.81,24.88,25.68,25.71,26.03$, 26.1, 29.0, 29.4, 30.9 and $31.3\left(\mathrm{CH}_{2}\right.$, cyclohexyl), 35.9 (C-6), 41.2 (C-3), 49.9 (C-2), 50.9 and 52.5 (C-1"'a and C-1"'b), 72.1 (C-5/4'), 117.1 (C-5"), 118.93 and 118.98 (C-3", C-1"), $127.2\left(\mathrm{C}-6^{\prime \prime}\right), 132.8$ (C-4"), 153.3 (C-2'), 163.5 (C-2"), 171.5 (C-7), 171.9 (C-5') ppm. HRMS $\left(\mathrm{ESI}^{+}\right): \mathrm{m} / z$ calcd for $\left[\mathrm{C}_{25} \mathrm{H}_{34} \mathrm{~N}_{4} \mathrm{O}_{3}+\mathrm{H}\right]^{+}: 439.2709$; found: 439.2742.

Compound 4b: $\mathrm{C}_{19} \mathrm{H}_{26} \mathrm{~N}_{4} \mathrm{O}_{3}$ (bright yellow crystal, molecular weight $358.43 \mathrm{~g} / \mathrm{mol}, 0.60 \mathrm{~g}$, yield $67 \%$, mp $\left.193-195{ }^{\circ} \mathrm{C}\right) .{ }^{1} \mathrm{H}$ $\operatorname{NMR}\left(300.13 \mathrm{MHz}, \mathrm{CDCl}_{3}\right): \delta=1.32,134$ and $1.47(3 \mathrm{~d}, J=6.9 \mathrm{~Hz}$, $3 \times 3 \mathrm{H}, \mathrm{CH}_{3}$, isopropyl), 1.43 (d, $J=6.8 \mathrm{~Hz}, 3 \mathrm{H}, \mathrm{CH}_{3}$, isopropyl), 1.86-1.97 (m, $1 \mathrm{H}, \mathrm{NH}), 3.00-3.07$ and 3.62-3.69 $(2 \mathrm{~m}, 2 \mathrm{H}, \mathrm{H}-$ 3), 3.27 and 3.32 (AB, $J=15.0 \mathrm{~Hz}, 2 \mathrm{H}, \mathrm{H}-6), 3.82-3.88$ and 4.134.19 (2 m, $2 \mathrm{H}, \mathrm{H}-2), 3.70-3.81$ and 4.19-4.28 (2 m, $2 \mathrm{H}, \mathrm{H}-1$ "'a, H-1"'b), 6.71-6.75 (m, $1 \mathrm{H}, \mathrm{H}-5$ "), 6.95 (dd, $J=8.3,1.1 \mathrm{~Hz}, 1 \mathrm{H}$, $\left.\mathrm{H}-3^{\prime \prime}\right), 7.22$ (dd, $\left.J=8.1,1.4 \mathrm{~Hz}, 1 \mathrm{H}, \mathrm{H}-6^{\prime \prime}\right), 7.26-7.30$ (m, $1 \mathrm{H}, \mathrm{H}-$ 4"), 15.75 (s, $1 \mathrm{H}, 2$ "-OH) ppm. ${ }^{13} \mathrm{C}$ NMR (75.47 MHz, $\left.\mathrm{CDCl}_{3}\right): \delta=$ 19.5, 19.8, 21.2 and 21.7 ( $\mathrm{CH}_{3}$, isopropyl), 36.0 (C-6), 41.5 (C-3), 43.4 and 44.5 (C-1"'a and C-1"'b), 50.2 (C-2), 72.2 (C-5/4'), 117.2 (C-5"), 119.0 (C-3"), 119.1 (C-1"), 127.3 (C-6"), 132.9 (C-4"), 153.2 (C-2'), 163.5 (C-2"), 171.5 (C-7), 172.0 (C-5') ppm. HRMS $\left(\mathrm{ESI}^{+}\right): \mathrm{m} / z$ calcd for $\left[\mathrm{C}_{19} \mathrm{H}_{26} \mathrm{~N}_{4} \mathrm{O}_{3}+\mathrm{H}\right]^{+}:$359.2083; found: 359.2115 .

(E,Z)-5-[2'-(2"-Hydroxyphenyl)-2'-oxoethylidene]-1,3-diisopropylimidazolidine-2,4-dione (7b)

$\mathrm{C}_{17} \mathrm{H}_{20} \mathrm{~N}_{2} \mathrm{O}_{4}$ (yellow solid, molecular weight $316.35 \mathrm{~g} / \mathrm{mol}, 0.06$ g, yield $8 \%$, mp $\left.144-145{ }^{\circ} \mathrm{C}\right) .{ }^{1} \mathrm{H}$ NMR $\left(300.13 \mathrm{MHz}, \mathrm{CDCl}_{3}\right): \delta=$ 1.46 and $1.49\left(2 \mathrm{~d}, J=6.9 \mathrm{~Hz}, 2 \times 6 \mathrm{H}, \mathrm{CH}_{3}\right.$, isopropyl), 4.32-4.55 (m, 2 H, H-1'"a, H-1'"b), 6.82 (s, 1 H, H-1'), 6.98-6.99 (m, 1 H, H5"), 7.02 (d, J = 8.4 Hz, $\left.1 \mathrm{H}, \mathrm{H}-3^{\prime \prime}\right), 7.47-7.57$ (m, $\left.1 \mathrm{H}, \mathrm{H}-4^{\prime \prime}\right), 7.84$ (d, $\left.J=8.1 \mathrm{~Hz}, 1 \mathrm{H}, \mathrm{H}-6^{\prime \prime}\right), 12.27$ (s, $\left.1 \mathrm{H}, 2^{\prime \prime}-\mathrm{OH}\right) \mathrm{ppm} .{ }^{13} \mathrm{C}$ NMR (75.47 $\left.\mathrm{MHz}, \mathrm{CDCl}_{3}\right): \delta=19.7$ and $20.0\left(\mathrm{CH}_{3}\right.$ isopropyl), 44.5 and 50.5 (C-1"'a and C-1"'b), 100.5 (C-1'), 118.6 (C-3"), $119.2\left(\mathrm{C}-5^{\prime \prime}\right)$, $120.8\left(\mathrm{C}-1^{\prime \prime}\right), 130.8\left(\mathrm{C}-6^{\prime \prime}\right), 137.0\left(\mathrm{C}-4^{\prime \prime}\right), 137.2(\mathrm{C}-5), 153.9(\mathrm{C}-2)$, 162.9 (C-2"), 1623.0 (C-4), 194.8 (C-2') ppm. HRMS (ESI $\left.{ }^{+}\right): \mathrm{m} / \mathrm{z}$ calcd for $\left[\mathrm{C}_{17} \mathrm{H}_{20} \mathrm{~N}_{2} \mathrm{O}_{4}+\mathrm{Na}\right]^{+}$: 339.1321; found: 339.1315 .

(21) Synthesis of $(R, S)-1 ', 3$ '-Dicyclohexyl-5-(2"-hydroxyphenyl)spiro[(E)-2,3,6,7-tetrahydro-2H-1,4-oxazepine-7,4'-imidazolidine]-2',5'-dione (5a)

$\mathrm{C}_{25} \mathrm{H}_{33} \mathrm{~N}_{3} \mathrm{O}_{4}$ (yellowish white solid, molecular weight 439.54 $\mathrm{g} / \mathrm{mol}, 0.65 \mathrm{~g}$, yield $59 \%$, mp $\left.96-97^{\circ} \mathrm{C}\right)$. Compound 1a (1g, 2.5 $\mathrm{mmol}$ ) was added to hydroxyethylene amine (or 2-aminoethanol) ( $1 \mathrm{~mL}, 16.5 \mathrm{mmol}$ ) in $\mathrm{CH}_{2} \mathrm{Cl}_{2}(20 \mathrm{~mL})$. The reaction mixture was stirred at r.t. for $4 \mathrm{~h}$. The volume of $\mathrm{CH}_{2} \mathrm{Cl}_{2}$ was then reduced to ca. $5 \mathrm{~mL}$ to be purified in short plug column chromatography using $\mathrm{CH}_{2} \mathrm{Cl}_{2}$ as eluent. The purified product 5a was precipitated in hexane. ${ }^{1} \mathrm{H}$ NMR $\left(300.13 \mathrm{MHz}, \mathrm{CDCl}_{3}\right): \delta=0.93-$ 2.30 ( $\mathrm{m}, 20 \mathrm{H}, \mathrm{CH}_{2}$, cyclohexyl), 2.57-2.60 (m, $\left.2 \mathrm{H}, \mathrm{H}-2\right), 3.11$ (tt, $J=12.0,3.5 \mathrm{~Hz}, 1 \mathrm{H}, \mathrm{H}-1$ '"a), 3.47 and 3.65 (AB, $J=17.8 \mathrm{~Hz}, 2 \mathrm{H}$, H-6), 3.62-3.73 (m, $2 \mathrm{H}, \mathrm{H}-3$ ), 3.97 (tt, $J=12.0,3.5 \mathrm{~Hz}, 1 \mathrm{H}, \mathrm{H}-$ 1"'b), 6.86-7.01 (m, 2 H, H-5", H-3"), 7.45-7.53 (m, $1 \mathrm{H}, \mathrm{H}-4 "$ ), 7.65 (dd, $\left.J=8.1,1.2 \mathrm{~Hz}, 1 \mathrm{H}, \mathrm{H}-6^{\prime \prime}\right), 11.74$ (s, $1 \mathrm{H}, 2^{\prime \prime}-\mathrm{OH}$ ) ppm. ${ }^{13} \mathrm{C}$ NMR $\left(75.47 \mathrm{MHz}, \mathrm{CDCl}_{3}\right): \delta=25.07,25.13,25.81,25.87$, 26.1, 26.2, 29.2, 29.3, 30.2 and $30.5\left(\mathrm{CH}_{2}\right.$, cyclohexyl), 42.4 (C-6), 42.7 (C-2), 51.5 (C-1'"b), 52.1 (C-1'"a), 61.5 (C-3), 75.5 (C-7/4'), 118.7 (C-1"), 118.9 (C-5"), 119.2 (C-3"), 129.2 (C-6"), 137.1 (C4"), 155.1 (C-2'), 162.6 (C-2"), 173.5 (C-5'), 200.5 (C-5) ppm. HRMS $\left(\mathrm{ESI}^{+}\right): \mathrm{m} / z$ calcd for $\left[\mathrm{C}_{25} \mathrm{H}_{33} \mathrm{~N}_{3} \mathrm{O}_{4} \mathrm{Na}\right]^{+}:$462.2369; found: 462.2342 .
(22) Synthesis of $(R, S)-1$ ',3'-Dicyclohexyl-4-(2"-hydroxyphenyl)spiro[(E)-2,3-dihydro-1H-benzo[b][1,4]diazepine-2,4'-imidazolidine]-2',5'-dione $(6 a)$ and $(R, S)-1^{\prime}, 3$ '-Diisopropyl-4-(2"hydroxyphenyl)-spiro[(E)-2,3-dihydro-1H-benzo[b][1,4]diazepine-2,4'-imidazolidine]-2',5'-dione (6b)

Compound $\mathbf{1 a}(1 \mathrm{~g}, 2.5 \mathrm{mmol})$ or $\mathbf{1 b}(0.8 \mathrm{~g}, 2.5 \mathrm{mmol})$, was added to ortho-phenylenediamine $(0.54 \mathrm{~g}, 5 \mathrm{mmol})$ in THF (40 $\mathrm{mL}$ ) in the presence of a catalytic amount of DBU (few drops). The reaction mixture was stirred at reflux overnight. After that, the solution was reduced to ca. $5 \mathrm{~mL}$ to be purified in short plug column chromatography using $\mathrm{CH}_{2} \mathrm{Cl}_{2}$ as eluent. The purified product $\mathbf{6 a}$ or $\mathbf{6 b}$, was recrystallized from a hexane- $\mathrm{CH}_{2} \mathrm{Cl}_{2}(5: 1)$ solution by slow evaporation at $6{ }^{\circ} \mathrm{C}$.

Compound 6a: $\mathrm{C}_{29} \mathrm{H}_{34} \mathrm{~N}_{4} \mathrm{O}_{3}$ (pale yellow crystal, molecular weight $486.60 \mathrm{~g} / \mathrm{mol}, 0.86 \mathrm{~g}$, yield $71 \%$, mp $\left.147-149{ }^{\circ} \mathrm{C}\right) .{ }^{1} \mathrm{H}$ $\operatorname{NMR}\left(300.13 \mathrm{MHz}, \mathrm{CDCl}_{3}\right): \delta=0.69-2.29\left(\mathrm{~m}, 20 \mathrm{H}, \mathrm{CH}_{2}\right.$, cyclohexyl), 2.99 and $3.33(\mathrm{AB}, J=14.0 \mathrm{~Hz}, 2 \mathrm{H}, \mathrm{H}-3), 3.06-3.19$ and 3.82-3.97 (2 m, 2 H, H-1"'a, H-1"'b), 3.77 (s, 1 H, NH), 6.82-6.88 (m, $\left.1 \mathrm{H}, \mathrm{H}-5^{\prime \prime}\right), 6.89-6.93$ (m, $\left.1 \mathrm{H}, \mathrm{H}-7\right), 7.04(\mathrm{~d}, J=8.8 \mathrm{~Hz}, 1 \mathrm{H}$, H-3"), 7.14-7.19 (m, 2 H, H-8 and H-9), 7.28-7.41 (m, 3 H, H-4", H-6", H-6), 14.71 (s, $1 \mathrm{H}, 2$ "-OH) ppm. ${ }^{13} \mathrm{C}$ NMR (75.47 MHz, $\left.\mathrm{CDCl}_{3}\right): \delta=22.6,24.8,25.7,25.8,25.9,26.1,29.2,29.4,30.8$ and $31.5\left(\mathrm{CH}_{2}\right.$, cyclohexyl), 33.5 (C-3), 51.3 and 51.7 (C-1"'a and C$\left.1^{\prime \prime \prime} b\right), 87.4$ (C-2/4'), 118.1 (C-5"), 118.5 (C-3"), 119.1 (C-1"), 121.5 (C-7), 123.6 (C-9), 127.6 (C-8), 128.1 (C-6), 128.5 (C-6"), 133.4 (C-4"), 135.3 (C-9a), 136.0 (C-5b), 152.7 (C-2'), 162.1 (C2"), 167.0 (C-4), $170.5\left(\mathrm{C}-5^{\prime}\right)$. HRMS $\left(\mathrm{ESI}^{+}\right): \mathrm{m} / \mathrm{z}$ calcd for $\left[\mathrm{C}_{29} \mathrm{H}_{34} \mathrm{~N}_{4} \mathrm{O}_{3}+\mathrm{Na}\right]^{+}$: 509.2529; found: 509.2527.Compound 6a: $\mathrm{C}_{23} \mathrm{H}_{26} \mathrm{~N}_{4} \mathrm{O}_{3}$ (bright yellow crystal, molecular weight $=406.47$ $\mathrm{g} / \mathrm{mol}, 0.64 \mathrm{~g}$, yield $63 \%$, mp $\left.181-182{ }^{\circ} \mathrm{C}\right) .{ }^{1} \mathrm{H}$ NMR $(300.13 \mathrm{MHz}$, $\left.\mathrm{CDCl}_{3}\right): \delta=1.33$ and $1.47\left(2 \mathrm{~d}, J=6.7 \mathrm{~Hz}, 2 \times 3 \mathrm{H}, \mathrm{CH}_{3}\right.$, isopropyl $)$, 1.41 and $1.44\left(2 \mathrm{~d}, J=7.2 \mathrm{~Hz}, 2 \times 3 \mathrm{H}, \mathrm{CH}_{3}\right.$, isopropyl), 3.00 and $3.32(\mathrm{AB}, J=14.0 \mathrm{~Hz}, 2 \mathrm{H}, \mathrm{H}-3)$, 3.56-3.69 and 4.25-4.39 (2 m, 2 H, H-1"'a, H-1"'b), 3.83 (s, 1 H, NH), 6.80-6.88 (m, 1 H, H-5"), 6.90-6.96 (m, $1 \mathrm{H}, \mathrm{H}-7$ ), 7.04 (d, J = 8.2 Hz, $\left.1 \mathrm{H}, \mathrm{H}-3^{\prime \prime}\right), 7.10-7.21$ ( $\mathrm{m}, 2 \mathrm{H}, \mathrm{H}-8$ and $\mathrm{H}-9), 7.24-7.42$ (m, $\left.3 \mathrm{H}, \mathrm{H}-4^{\prime \prime}, \mathrm{H}-6^{\prime \prime}, \mathrm{H}-6\right)$, $14.74\left(\mathrm{~s}, 1 \mathrm{H}, 2\right.$ "-OH) ppm. ${ }^{13} \mathrm{C}$ NMR $\left(75.47 \mathrm{MHz}, \mathrm{CDCl}_{3}\right): \delta=$ 19.6, 19.7, 22.0 and $21.6\left(\mathrm{CH}_{3}\right.$, isopropyl), $33.5(\mathrm{C}-3), 43.7$ and 45.6 (C-1"'a and C-1"'b), 87.1 (C-2/4'), $118.1\left(\mathrm{C}-5^{\prime \prime}\right), 118.6$ (C3"), 119.2 (C-1"), 121.6 (C-7), 123.6 (C-9), 127.7 (C-8), 128.3 (C6), 128.6 (C-6"), 133.4 (C-4"), 135.3 (C-9a), 135.8 (C-5b), 152.5 (C-2'), $162.2\left(\mathrm{C}-2^{\prime \prime}\right), 166.7(\mathrm{C}-4), 170.6\left(\mathrm{C}-5^{\prime}\right)$. HRMS (ESI $\left.{ }^{+}\right): \mathrm{m} / \mathrm{z}$ calcd for $\left[\mathrm{C}_{23} \mathrm{H}_{26} \mathrm{~N}_{4} \mathrm{O}_{3}+\mathrm{Na}\right]^{+}$: 407.2083; found: 407.2100.

(23) Crystal Data for Compound 2a

$2 \times \mathrm{C}_{24} \mathrm{H}_{32} \mathrm{~N}_{4} \mathrm{O}_{3}+\mathrm{C}_{3} \mathrm{H}_{6} \mathrm{O}, M=907.15$, monoclinic, space group $C 2 / c, \quad Z=4, \quad a=29.894(3) \AA, \quad b=8.2853(8) \AA, \quad c=22.364(2) \AA$, $\beta=120.814(4)^{\circ}, \quad V=4757.1(8) \AA^{3}, \quad \mu($ Mo $\mathrm{K} \alpha)=0.085 \mathrm{~mm}^{-1}$, $D_{\mathrm{c}}=1.267 \mathrm{~g} \mathrm{~cm}^{-3}$, colorless block, crystal size of $0.26 \times 0.20 \times$ $0.18 \mathrm{~mm}^{3}$. Of a total of 68339 reflections collected, 6395 were independent $\left(R_{\mathrm{int}}=0.0615\right)$. Final $R 1=0.0438[I>2 \sigma(I)]$ and $w R 2=0.1201$ (all data). Data completeness to $\theta=25.24^{\circ}, 99.7 \%$. CCDC 1024617.

(24) Crystal Data for Compound $4 \mathbf{b}$ $\mathrm{C}_{19} \mathrm{H}_{26} \mathrm{~N}_{4} \mathrm{O}_{3}, M=358.44$, monoclinic, space group $P 2{ }_{1} / \mathrm{c}, Z=4$, $a=10.3118(13) \AA, \quad b=10.8672(14) \AA, \quad c=17.551(2) \AA$, $\beta=105.671(4)^{\circ}, \quad V=1893.7(4) \AA^{3}, \quad \mu($ Mo $K \alpha)=0.087 \mathrm{~mm}^{-1}$, $D_{\mathrm{c}}=1.257 \mathrm{~g} \mathrm{~cm}^{-3}$, yellow block, crystal size of $0.30 \times 0.28 \times 0.24$ $\mathrm{mm}^{3}$. Of a total of 50806 reflections collected, 5091 were independent $\left(R_{\text {int }}=0.0341\right)$. Final $R 1=0.0453 \quad[I>2 \sigma(I)]$ and $w R 2=0.1219$ (all data). Data completeness to $\theta=25.24^{\circ}, 99.9 \%$. CCDC 1024618 . 


\section{(25) Crystal Data for Compound 6b}

$\mathrm{C}_{23} \mathrm{H}_{26} \mathrm{~N}_{4} \mathrm{O}_{3}+\mathrm{CH}_{2} \mathrm{Cl}_{2}, M=491.40$, monoclinic, space group $P 2_{1} / \mathrm{c}$, $Z=4, \quad a=14.4092(9) \AA, \quad b=9.1504(5) \AA, \quad c=18.5751(11) \AA$, $\beta=98.7540(19)^{\circ}, \quad V=2420.6(2) \AA^{3}, \mu($ Mo $K \alpha)=0.302 \mathrm{~mm}^{-1}$,

$D_{\mathrm{c}}=1.348 \mathrm{~g} \mathrm{~cm}^{-3}$, yellow prism, crystal size of $0.20 \times 0.20 \times 0.16$ $\mathrm{mm}^{3}$. Of a total of 19864 reflections collected, 6504 were independent $\quad\left(R_{\text {int }}=0.0332\right)$. Final $R 1=0.0741 \quad[I>2 \sigma(I)]$ and $w R 2=0.1817$ (all data). Data completeness to $\theta=25.24^{\circ}, 99.8 \%$. CCDC 1024619. 